\title{
Pro oxidants and Antioxidants Levels in Chronic Renal Failure Patients Treated by Dialysis
}

\author{
Neetha Kundoor ${ }^{1 *}$, Shruti Mohanty ${ }^{2}$, Radha Kishan Narsini ${ }^{1}$ and T. Naveen Kumar ${ }^{3}$ \\ 'Apollo Institute of Medical Sciences and Research, Department of Biochemistry, Hyderabad - 500033, \\ Telangana, India \\ ${ }^{2}$ Principal \& Professor, Department of Biochemistry, Kamineni Institute of Medical Sciences, Narketpally, \\ Telangana, India \\ ${ }^{3}$ Apollo Institute of Medical Sciences and Research, Department of Pharmacology, Hyderabad - 500033, \\ Telangana, India
}

\begin{abstract}
To assess adjustments in star oxidant and cancer prevention agent state in pre and post hemodialysis patients experiencing ceaseless renal disease. The study was led on 100 perpetual renal disappointment patients going to outpatient division of nephrology dialysis unit in relationship with bureau of organic chemistry at Kamineni establishment of therapeutic Sciences, Narketpally, Nalgonda district, Telangana. Age between 30-70 years of either sex measuring their estimated oxidant levels of serum malondialdehyde, serum protein carbonyls and anti-oxidant levels of serum superoxide dismutase, serum catalase prior and then afterward the dialysis session coordinated controls. In the present study, we have observed significant increase in levels of pro-oxidants serum malondialdehyde and serum protein carbonyls fixation and there was reduction in chemical action of cell reinforcement serum superoxide dismutase and serum catalase. Our study highlights the need of screening of cancerous agents in renal Patients in regular intervals for better treatment outcomes and also to improve quality of life of the patients.
\end{abstract}

Keywords: Antioxidants, Chronic Kidney Disease, Dialysis, Pro Oxidants

\section{Introduction}

Chronic renal disease includes a variety of dysfunction of kidneys, which decreases the filtration rate and overall efficiency of kidney. It is a condition in which there has been a permanent loss of renal limit, of a degree sufficient to render the patient everlastingly subordinate upon renal substitution treatment with a particular true objective to keep up a key separation from life-weakening uremia. Uremia is the clinical and research focus issue, shimmering brokenness of all organ systems along these lines of untreated or under treated extreme or endless renal failure ${ }^{1}$.

The treatment for Chronic kidney sickness can be either dialysis or renal transplantation ${ }^{2}$. Over the most recent decade accessible oxygen genus (ROS) assume a input in pathophysiology of extensive assortment of renal ailments by trial evidence ${ }^{3}$.

The most imperative free radicals in numerous illness states are oxygen subsidiaries, especially superoxide $\left(\mathrm{O}_{2}\right.$ ), hydroxyl radical ( $\mathrm{OH}-)$, hydroperoxy radical (HOO), lipid peroxide radical (ROO), Nitric Oxide (NO), peroxy nitrite (ONOO) are in charge of a significant number of organic impacts of free radical inside the human body ${ }^{4}$. Free radicals contributes to cell damage through lipid peroxidation of membranes, oxidative adjustments of proteins and damage of nucleic acids ${ }^{5-7}$.

The harming impacts of ROS can be controlled by different cancer prevention agent defence systems, for example, catalase, glutathione peroxidases, superoxidase dismutase ${ }^{8-10}$. The present study was undertaken to observe Pro oxidants and antioxidants levels in chronic renal failure patients treated by dialysis.

\section{Methods}

The current study was conducted in department of nephrology (dialysis unit) in relationship with the branch

${ }^{*}$ Author for correspondence 
of natural chemistry, Kamineni institute of restorative sciences, Narketpally, Nalgonda district,Telangana.100 patients were incorporated into the review isolated into 3 groups. The study protocol was approved by institutional ethical committee and informed consent was obtained from all the participants.

Group A and B: 50 patients experiencing pre and post hemodialysis.

Group C: 50 controls

Inclusion Criteria: Patients with kidney ailment experiencing hemodialysis over 6 months.

Exclusion Criteria: Patients experiencing hemodialysis with intense renal disappointment, patients experiencing tuberculosis, harm and renal transplant patients experiencing hemodialysis.

\subsection{Collection of the Blood Sample for Analysis}

$5 \mathrm{ml}$ of venous blood was collected from participants of both the groups and centrifuged at 3000 pivots for every moment for 10 minutes and the serum was isolated and collected from the rotator tubes and stored at $-20^{\circ} \mathrm{C}$ until investigated.

\subsection{Biochemical Assays}

Blood urea and serum creatinine concentration was measured by berthlot method and jaffe's method ${ }^{11,12}$. Serum Malondialdehyde (MDA) and serum protein carbonyls measured by thibarbituric corrosive receptive substance assay (TBARS) and ELISA pack technique ${ }^{13}$. Serum superoxide dismutase (SOD) was measured by hindrance of auto oxidation of adrenaline by superoxide dismutase method and serum catalase was measured by goth's method $^{14,15}$.

\subsection{Statistical Analysis}

The outcomes were expressed as mean and standard deviation. Note worthiness of distinction among patients before and after haemodialysis data was surveyed by matched ' $t$ '- test. Student't' test was utilized for significance of distinction between the diverse patients and control bunches. The limit of importance was picked as $\mathrm{P}<0.005$. Connection co-productive (pearson's connection) was computed to quantify the relationship among the factors.

\section{Results}

Table 1. Clinical characteristics of the studied groups

\begin{tabular}{lcc}
\hline Age /years & $\begin{array}{c}\text { Controls } \\
\mathbf{N =} \mathbf{5 0}\end{array}$ & $\begin{array}{c}\text { Patients } \mathbf{N}=\mathbf{5 0} \text { (pre } \\
\text { and post dialysis) }\end{array}$ \\
\hline $30-40$ & 7 & 7 \\
$41-50$ & 12 & 11 \\
$51-60$ & 21 & 14 \\
$>60$ & 10 & 18 \\
\hline Total & $\mathbf{5 0}$ & $\mathbf{5 0}$ \\
\hline
\end{tabular}

Table 2. Sex distribution

\section{PATIENTGROUP(N=50)}

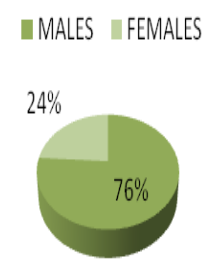

Table 3. Changes in biochemical parameters of predialysis, post dialysis and control patients. Group A: Pre hemodialysis, Group B: Post hemodialysis, Group C: Controls P $<0.05$ significant, MDA - Malondialdehyde, NS: Not significant

\begin{tabular}{lcccc}
\hline Parameters $($ mean \pm SD) & Group A N =50 & Group B N =50 & Group C N =50 & P value \\
\hline Blood urea $(\mathrm{mg} / \mathrm{dl})$ & $117 \pm 22.94$ & $52.3 \pm 19.48$ & $29.3 \pm 7.46$ & $<0.0001$ \\
Serum creatinine $(\mathrm{mg} / \mathrm{dl})$ & $4.30 \pm 2.69$ & $2.92 \pm 2.25$ & $0.97 \pm 0.26$ & $<0.0001$ \\
Serum MDA concentration $(\mathrm{mmol} / \mathrm{ml})$ & $290.34 \pm 11.34$ & $328.52 \pm 17.48$ & $238.92 \pm 17.8$ & $<0.0001$ \\
Serum Protein carbonyls $(\mathrm{nmol} / \mathrm{ml})$ & $0.148 \pm 0.015$ & $0.186 \pm 0.011$ & $0.046 \pm 0.011$ & $<0.0001$ \\
Serum catalase $(\mathrm{ku} / \mathrm{l})$ & $62.38 \pm 6.21$ & \pm 5.97 & - & $>0.05 \mathrm{NS}$ \\
Serum superoxide -dismutase $($ activity & $141.22 \pm 11.37$ & $128.34 \pm 17.50$ & $153.92 \pm 16.19$ & $<0.0001$ \\
/gm protein) & & & & \\
\hline
\end{tabular}

72 | Vol 9 (2) | 2017 | www.informaticsjournals.org/index.php/ajprhc 


\section{Discussion}

Each cell in the body was equipped with self protective mechanisms to protect themselves from free radicals. This includes presence of enzymes especially Superoxide dismutase, Catalase, Glutathione Peroxidase, which can detoxify the free radicals. Loss pf balance between the Oxidants and Antioxidants will leads to oxidative stress. The harmony between arrangement of receptive oxygen species and ant oxidative resistance system depends on the cellular enzyme network. Oxidative stress is more common in the renal patients who are undergoing dialysis.

Table 3 presents oxidants serum MDA levels and serum protein carbonyls demonstrated noteworthy increment in post dialysis patients when contrasted and predialysis patients ${ }^{16-18}$. Antioxidants serum superoxide - dismutase indicated huge reduction in contrast with serum catalase $\mathrm{e}^{19,20}$.

It has been accounted for that dialysis layers utilized as a part of hemodialysis modify the oxidative digestion system of polymorph atomic leucocytes.

The layers utilized as a part of hemodialysis are influenced by plasma proteins which have distinctive sub-atomic weights. These proteins change the reactivity of the dialysis layers, anticipate film cell collaboration. Neutrophil activation and free oxygen radicals are expanded in regard to measure of consumed proteins.

\section{Conclusion}

In the present study, we have observed significant increase in levels of pro-oxidants serum malondialdehyde and serum protein carbonyls fixation and there was reduction in chemical action of cell reinforcement serum superoxide dismutase and serum catalase. Our study highlights the need of screening of cancerous agents in renal Patients in regular intervals for better treatment outcomes and also to improve quality of life of the patients.

\section{References}

1. Anthony SF, Dennis LK, Eugene B, Stephen LH, Larry J. Chronickidney disease. In: Anthony SF, Dennis LK, Eugene B, Stephen LH, Larry J, editors. Harrison's principles of internal medicine. 17th ed. New Delhi: McGraw-Hill Companies; 2008. p. 1761-71.

2. Dakshinamurthy KV, Rao PVLNS, Saibaba KSS, Sheela RB.
Antioxidant status in patients on maintenance hemodialysis. Indian J Nephrol. 2002; 12:77-80.

3. Ichikawa I, Kiyama S, Yoshioka T. Renal antioxidant enzymes: Their regulation and function. Kidney Int. 1994; 45:1-9. PMid:8126996. Available from: https://doi. org/10.1038/ki.1994.1

4. Massy ZA, Nguyen-Khoa T. Oxidative stress and chronic renal failure: Markers and management. J Nephrol. 2002; 15: 336-41. PMid:12243361.

5. Barber A, Bernheim F. Lipid peroxidation: Its measurements, occurrence and significance in animal tissues. Adv Gerontal Res. 1967; 2:355-03. PMid:5339163.

6. Fridovich I. The biology of oxygen radicals. Science. 1978; 201:875-80. PMid:210504 Available from: https://doi. org/10.1126/science. 210504

7. Southorn PA, Powis G. Free radicals in medicine I and II. Mayo Clinic Proc. 1988; 63:381-08. Available from: https:// doi.org/10.1016/S0025-6196(12)64861-7

8. Young IS, Woodside JV. Antioxidants in health and disease. J Clin Pathol. 2001; 54:170-80. PMCid:PMC1731363. Available from: https://doi.org/10.1136/jcp.54.3.176

9. Martin-Mateo MC, del Canto-Jafiez E, Barrero-Martinez MJ. OS and enzyme activity in ambulatory renal patients undergoing continuous peritoneal dialysis. Renal Fail. 1998; 20:117-24. Available from: https://doi. org/10.3109/08860229809045094

10. Mimic-Oka J, Simic T, Djukanovic L, Reljic Z, Davicevic Z. Alteration in plasma antioxidant capacity in various degrees of CRF. Clin Nephrol. 1999; 51:233-41. PMid:10230556.

11. Fawcett JK, Scott. A rapid and precise method for the determination of urea. J Clin Path. 1960; 13:156-9. PMid:13821779 PMCid:PMC480024. Available from: https://doi.org/10.1136/jcp.13.2.156

12. Patton. CJ, Crouch SR. Spectrophotometric and kinetics investigation of the Berthelot reaction for the determination of ammonia. Anal Chem. 1977; 49:464-9. Available from: https://doi.org/10.1021/ac50011a034

13. Bird RP, Draper HH. Comparative study on different methods of MDA determination. Methods Enzymol. 1984; 105:299-05. Available from: https://doi.org/10.1016/S00766879(84)05038-2

14. Menesve E, Sivrikaya A, Karagozoglu E, Ali Muhtar Tiftik. Study of elements, antioxidants and lipid Peroxidation in hemodialysis patients. Turk J Med Sci. 2006; 36: 279-84.

15. Aebi HE, Bergmeyer HU. Catalase in methods of enzymatic analysis. 3rd ed. Weinheim: Verlag Chemie. 1983; 273-86.

16. Esma M, Abdulla S, Emrah K, Ali Muhtar T. Study of elements, antioxidants and lipid Peroxidation in hemodialysis patients. Turk J Med Sci. 2006; 36:279-84.

17. Himmelfarb J, McMonagle E, McMenamin E. Plasma protein thiol oxidation and carbonyl formation in chronic renal failure. Kidney Int. 2000; 58:2571-8. PMid:11115093. Available from: https://doi.org/10.1046/j.15231755.2000.00443.x

18. Ward RA, Ouseph R, Mcleish KR. Effects of high-fluxhe- 
modialysis on oxidant stress. Kidney International. 2003; 63:353-9. PMid:12472803. Available from: https://doi. org/10.1046/j.1523-1755.2003.00741.x

19. Sohji N, Kazumasa A, Aki H, Michihiro G, Atsushi U. Favourable effect of hemodialysis on decreased serum antioxidant activity in hemodialysis patients demonstrated by electron spin resonance. Journal of the American Society of Nephrology. 1997; 8:1157-63.
20. Paik-Seong L, Yau-Huei W, York Leng Y, Benny K. Enhanced oxidative stress in hemodialysis patients receiving intravenous iron therapy. Nephrol Dial Transplant. 1999; 14:2680-7. Available from: https://doi.org/10.1093/ ndt/14.11.2680

21. Necip I, Ahmet V. Evaluation of oxidative damage during hemodialysis with different dialysis membranes. T Klin Med Res. 2002; 20:60-4. 